\title{
Effects of microalgae on nutrient removal from mariculture wastewater in Can Gio District, Ho Chi Minh City, Vietnam
}

\author{
Hiệu quả của vi tảo trong việc loại bỏ các chất dinh duõng gây ô nhiễm trong \\ nước thải nuôi trồng thủy hải sản ở huyện Cần Giờ, thành phố Hồ Chí Minh,
} Việt Nam

Research Article

Le Hung Anh ${ }^{1}$, Vo Thi Kim Khuyen ${ }^{2}$, Trinh Ngoc Nam ${ }^{3}$, Vo Duy Khoa

${ }^{1}$ Institute of Environmental Science, Engineering and Management, Industrial University of Ho Chi Minh City, Vietnam ${ }^{2}$ Department of Biosciences and Chemistry, Faculty of Health and Wellbeing, Sheffield Hallam University, England ${ }^{3}$ Institute of Biotechnology and Food Technology, Industrial University of Ho Chi Minh City, Vietnam

${ }^{4}$ Department Anesthesia and Intensive Care, Nguyen Tri Phuong Hospital, Vietnam

\begin{abstract}
Mariculture has currently brought greatly valuable products in many fields simultaneously released a large amount of wastewater contributing to water pollutions on account of its organic and inorganic constituents. Nowadays, with the development of environmental engineering, more and more approaches, especially friendly-environmental and highly effective wastewater biological methods, are being applied to tackle pollutions and minimize adverse effects of treatments to reach the sustainable development. This report focuses on the study of proliferation combined with elimination of polluting substances of marine algae species Tetraselmis suiscica, Tetraselmis sp., Platymonas sp. in aquaculture wastewater sampled from Can Gio District, Ho Chi Minh City, Vietnam with levels of concentration during 14 days under normal marine algae culture conditions, and compared to that in Daigo's IMK media. The results shown that, the algae species all grew rapidly simultaneously gave high nutrients removal yields (COD, N, P) and created a considerable amount of biomass within a short period of culture. Particularly, Platomonas $s p$. and Tetraselmis suiscica could proliferate as well as give high treatment yields of organic substances (COD), $\mathrm{PO}_{4}{ }^{3-}, \mathrm{NO}_{3}{ }^{-}, \mathrm{NH}_{4}{ }^{+}$and Total Nitrogen in concentrated wastewater. To sum up, this study showed the potential of using microalgae to reduce $\mathrm{COD}$, nitrogen and phosphorus in mariculture wastewater.
\end{abstract}

\begin{abstract}
Ngành nuôi trồng thủy hải sản trong những nằm gần đây đã mang lại nhiều sản phẩm có giá trị trong nhiều lĩnh vưc đồng thời thải ra một lương lớn nước thải gây ô nhiễm nguồn nuớc bởi các thành phần vô co và hưu co có trong nước thải. Ngày nay, với sự phát triển của kỹ thuật môi trường, ngày càng nhiều cách tiếp cận, đặc biệt là các phuoong pháp sinh học hiệu quả cao và thân thiện với môi truờng đang được ưng dụng để xủ lý ô nhiễm và giảm thiểu hậu quả bất lợi sau xủ lý, nhằm huớng tới sự phát triển bền vững. Bài báo cáo tập trung nghiên cưu khả năng sinh truởng và phát triển của ba loài vi tảo biển Tetraselmis suiscica, Tetraselmis sp., Platymonas sp. kết hợp với việc loại bỏ các hơp chất gây ô nhiếm có trong nước thải tù ao nuôi tôm của huyện Cần Giờ, Việt Nam và so sánh đối chiếu với môi trường dinh duõng Daigo's IMK trong 14 ngày nuôi trồng. Kết quả cho thấy những vi tảo sinh trưởng rẩt nhanh nhờ vào việc sử dụng các chất ô nhiếm trong nước thải, đặc biệt hiệu suất xử lý $\mathrm{COD}, \mathrm{PO}_{4}{ }^{3-}, \mathrm{NO}_{3}^{-}, \mathrm{NH}_{4}^{+}$và nito tổng của Platomonas sp. và Tetraselmis suiscica rất cao thậm chi trong môi truờng nuớc thải đậm đặc. Do đó, chúng tôi kết luận, vi tảo có tiềm năng rất lớn trong việc giảm nồng độ chất hữu co, phốt pho và nitơ trong nuớc thải nuôi trồng thủy hải sản.
\end{abstract}

Keywords: COD, mariculture, microalgae, nutrient removal, wastewater 


\section{Introduction}

Vietnam has favorable natural conditions for agricultural and industrial development especially aquaculture-shrimp industry bringing numerous profits particularly in Can Gio District, Ho Chi Minh City. However, large-scale shrimp farming is releasing much wastewater with a wide range of components called "nutrients" mainly biodegradable organic substances, phosphorus, nitrogen, algae species, causing pollution and requiring reasonable treatments. Moreover, people have currently faced an energy crisis and air pollution because of the future exhaustion of fossil fuel. Therefore, producing cleaner and cheaper energy from biomass is a potential for long-term uses.

Algae are classified into macro-algae "seaweed" and micro-algae which are unicellular algae, mainly eukaryotic microalgae Chlorophytes (green algae) and prokaryotic cyanobacteria (blue-green algae) (Cai et al., 2013). Micro-algae grow through transferring light, $\mathrm{CO}_{2}$ and substances as "nutrients" in wastewater or even dead lands into energyrich biomass $\mathrm{CO}_{0.48} \mathrm{H}_{1.83} \mathrm{~N}_{0.11} \mathrm{P}_{0.01}$ (Chisti, 2007; Chen et al., 2010) more rapidly than terrestrial plants (Pittman et al., 2011; Rawat et al., 2011) particularly double amount of biomass per day within 6h (Michael et al. 2010), which is feasibly employed for the production of biodiesel, bioethanol, biomethane and biohydrogen (Figure 1) (Schenk et al., 2008, Chinnasamy et al., 2010, Agwa et al., 2012). Therefore, microalgae are commercialized as a green effective secondary wastewater treatment where pollutants are reduced significantly (Rawat et al., 2011) by fixed biofilm or suspended growth operations (Logan and Ronald, 2011; Abdel-Raouf et al., 2012) including raceway ponds since 1950 s and photo-bioreactors with more advantages in well-controlled long culturing and producing larger quantities of biomass (Amit et al., 2010), for example, $100,000 \mathrm{~kg} /$ year with higher biomass concentration in broth, $4.00 \mathrm{~kg} / \mathrm{m}^{3}$ compared to 0.14 of the former (Chisti, 2007).

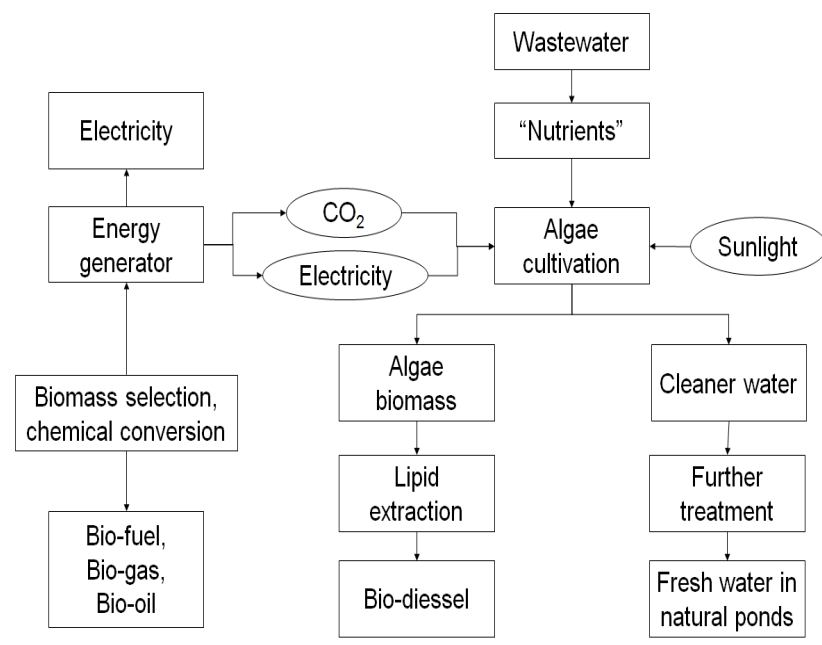

Figure 1. Diagram from waste to energy using algae (Extracted from Pittman et al., 2011)

There have recently been studies about proliferation and nutrients removal efficiency of many algal species especially Chlorella vulgaris and Chlorella sp. with dramatic density increase, high quality and quantity biomass (Gouveia and Oliveira, 2009), high removal efficiency of ammonia and COD but slightly low removal rate of total phosphorus (Sriram and Seenivasan, 2012), for examples of Chlorella vulgaris, results of Valderrama et al. (2001) indicating $2 \times 10^{6}$ cells $/ \mathrm{ml}$ of cell density, $28 \%, 71.6 \%$ and $61 \%$, respectively in 4-day culture with diluted (10\%) anaerobic industrial effluent; or studies of Li et al. (2011) presenting $80.9 \%, 93.9 \%$ and $90.8 \%$, respectively in 14 -day incubation with highly concentrated municipal wastewater. In addition, concentrations of metal ions typically $\mathrm{Al}, \mathrm{Ca}$, $\mathrm{Mg}, \mathrm{Mn}, \mathrm{Fe}$ were significantly reduced in wastewater from different points of treatment process of a municipal wastewater treatment plant by the algae according to Wang et al. (2009). The effects of culturing factors especially light/dark cycles on removal rate were also researched. For instance, Lee et al. (2001) showed that cell density and nitrate removal rate of Chlorella kessleri in the continuous illumination were higher than that under diurnal illuminating scheme while organic carbon was removed better in $12 \mathrm{~h}$ light $/ 12 \mathrm{~h}$ dark cycles.

To support a theory that algae are considered to be as a strategy of sustainable development on behalf of their highly friendly-environmental, economical and effective fucntions in wastewater treatment, this report investigated the performances of nutrient removals in shrimp wastewaters containing mainly non-biodegradable organic substances and a small amount of heavy metals of Tetraselmis suiscica, Tetraselmis sp., Platymonas sp. under well-controlled parameters optimal to proliferation of almost algae (Laura and Paolo, 2006), $25-35^{\circ} \mathrm{C}$, $\mathrm{pH}$ of 8.28.7 , light intensities of 4000-5000lux in continuous illumination, salinities of about $18.6 \%$ in Daigo's IMK medium and in wastewater sampled from shrimp cultivation ponds at Can Gio District, Ho Chi Minh City, Vietnam.

\section{Materials and Methods}

\subsection{Sampling and storage}

After being collected from planned points in wastewater ponds using polyethylene 5liter bottles with plastic lid, samples are transported to the laboratory under cool conditions without sunlight and stored at $5 \pm 3^{\circ} \mathrm{C}$ (ISO 19458:2006).

Purified species Tetraselmis suiscica, Tetraselmis sp., Platymonas sp. provided by Research Institute for Aquaculture No.2, Ho Chi Minh City, Vietnam were stored at $5 \pm 3^{\circ} \mathrm{C}$.

\subsection{Algae culture condition}

Daigo's IMK medium was prepared from the following chemicals: $\mathrm{NaNO}_{3} \quad 200 \mathrm{mg} / \mathrm{L}, \quad \mathrm{CaCl}_{2} .2 \mathrm{H}_{2} \mathrm{O} \quad 50 \mathrm{mg} / \mathrm{L}$, $\mathrm{K}_{2} \mathrm{HPO}_{4} 5 \mathrm{mg} / \mathrm{L}, \mathrm{Na}_{2} \mathrm{HPO}_{4} 1.4 \mathrm{mg} / \mathrm{L}, \mathrm{NH}_{4} \mathrm{Cl} 2.68 \mathrm{mg} / \mathrm{L}, \mathrm{Fe}-$ EDTA $5.2 \mathrm{mg} / \mathrm{L}$, Mn-EDTA $332 \mu \mathrm{g} / \mathrm{L}, \mathrm{Na}_{2}$ EDTA $5.2 \mathrm{mg} / \mathrm{L}$, $\mathrm{ZnSO}_{4} .7 \mathrm{H}_{2} \mathrm{O} \quad 23 \mu \mathrm{g} / \mathrm{L}, \quad \mathrm{CoSO}_{4} .7 \mathrm{H}_{2} \mathrm{O} \quad 14 \mu \mathrm{g} / \mathrm{L}$, $\mathrm{Na}_{2} \mathrm{MoO}_{4} .2 \mathrm{H}_{2} \mathrm{O} 7.3 \mu \mathrm{g} / \mathrm{L}, \mathrm{CuSO}_{4} .5 \mathrm{H}_{2} \mathrm{O} 2.5 \mu \mathrm{g} / \mathrm{L}, \mathrm{H}_{2} \mathrm{SeO}_{3}$ $1.7 \mu \mathrm{g} / \mathrm{L}, \mathrm{MnCl}_{2} .4 \mathrm{H}_{2} \mathrm{O} 180 \mu \mathrm{g} / \mathrm{L}$, thiamin. $\mathrm{HCl} 200 \mu \mathrm{g} / \mathrm{L}$, biotin $1.5 \mu \mathrm{g} / \mathrm{L}$, vitamin $\mathrm{B} 121.5 \mu \mathrm{g} / \mathrm{L}$, and appropriate amount of $\mathrm{NaCl}$ to obtain the same salinity as wastewater, approximately $3.5 \% \mathrm{NaCl}$.

Algae were inoculated at $15 \%\left(\mathrm{~V}_{\text {algae }} / \mathrm{V}_{\text {media }}\right)$ in $250 \mathrm{~mL}$ erlenmeyer flasks containing 100mL Daigo's IMK medium, and incubated in stationary conditions at $30 \pm 2^{\circ} \mathrm{C}, 4000$ - 
5000lux to obtain the primary generations, which were then multiplied in 1 litre to reach enough cells, roughly 1.5 $2.0 \times 10^{6}$ cells $/ \mathrm{ml}$ to find the optimal wavelength and make the cell density curve (absorbance, cells $/ \mathrm{ml}$ ) for each species by using the spectrometer (UV/VIS Genesys 20 Thermo spectronic), combined with the haemocytometer and microscope.

After achieving sufficient cells, they were cultivated in 5 litre plastic bottles containing wastewater (WW) with different concentrations $(25 \%, 50 \%, 75 \%, 100 \%)$ in the same conditions as that of Daigo's IMK culture to compare, evaluate the treatment yields, biomass weight and determine best suitable wastewater concentrations for each species' proliferation.

\subsection{Determination of algal growth}

Samples were taken from the culture media every day to measure optical density (OD) at the optimal wavelength by spectrometer and haemocytometer. Each recorded OD was corrected by subtracting that of the corresponding blank sample.

\subsection{Algae harvesting}

Algae were harvested mechanically on the day when the cell number is maximum by centrifugation, most rapid and reliable method (Logan and Ronald, 2011). After being taken $100 \mathrm{ml}$, samples were dried at $50^{\circ} \mathrm{C}$ and centrifuged at $6000 \mathrm{rpm}$ in 10 minutes, then tubes and samples were weighed, and the biomass was calculated by this equation:

$$
\mathrm{m}_{\text {biomass }}=\mathrm{m}_{\text {samples }+ \text { tubes }}-\mathrm{m}_{\text {centrifuge tubes }}
$$

\subsection{Analysis of wastewaters}

All the experiments were carried out in triplicate and average values of absorbance were recorded.

All wastewater samples were filtered using glass microfiber filters (Whatman, USA) to remove native bacteria and large particles. Ammonium $\left(\mathrm{N}-\mathrm{NH}_{4}{ }^{+}\right)$, nitrate $\left(\mathrm{N}-\mathrm{NO}_{3}{ }^{-}\right)$, phosphorus $\left(\mathrm{P}-\mathrm{PO}_{4}{ }^{3-}\right)$, total nitrogen $(\mathrm{TN})$ and COD were determined by colorimetry, Kjeldahl and titration, following Standard Methods 5220-COD, 4500-Nitrogen, $\mathrm{NH}_{3}, 4500$.E-Phosphorus. These parameters were determined in input of each batch (wastewater sampled from Can Gio District) and in output of each batch to make the comparisons and calculate the removal efficiency of each species.

\section{Results}

\subsection{Determination of optimal wavelength and cell density curve}

Results of scanning the absorbance shows although different algal species gave different maxima peak, their wavelength was in visible region, their density curve

had the format of straight line according to Lambert-Beer law.

Tetraselmis suiscica: $\mathrm{y}=23.731 \mathrm{x}+0.9502\left(\mathrm{R}^{2}=0.9921\right)$ at $\lambda=420 \mathrm{~nm}$,
Tetraselmis sp.: $\mathrm{y}=20.477 \mathrm{x}+0.2906\left(\mathrm{R}^{2}=0.9938\right)$ at $\lambda=$ 420nm,

Platymonas sp.: $\mathrm{y}=24.733 \mathrm{x}+0.3616\left(\mathrm{R}^{2}=0.9924\right)$ at $\lambda$ $=680 \mathrm{~nm}$.

\subsection{Selection of suitable dilution of wastewater for the algae growth}

From Figure 2, 3, 4 and Table 1, the cell number and biomass of Tetraselmis suiscica, Tetraselmis sp, Platymonas $s p$ surged similarly after a week culture from about $2 \times 10^{6}$ cells $/ \mathrm{ml}$ in relatively concentrated wastewaters $(50 \%, 75 \%$, even $100 \%$ ) and reached the peak of around 10-12 million cells $/ \mathrm{ml}$ on the beginning days of the second weeks (days of 3,4 in the figures), particularly $11.2 \times 10^{6}$ cells $/ \mathrm{ml}$ with the weight of $0.8612 \mathrm{~g} / \mathrm{ml}$ on the days of 4 in $75 \% \mathrm{WW}$, $11.06 \times 10^{6}$ cells $/ \mathrm{ml}$ with the weight of $0.2684 \mathrm{~g} / \mathrm{ml}$ on the days of 4 in $50 \% \mathrm{WW}, 10.95 \times 10^{6}$ cells $/ \mathrm{ml}$ with the weight of $0.4578 \mathrm{~g} / \mathrm{ml}$ on the days of 5 in $75 \% \mathrm{WW}$, respectively, but then decreased gradually in the ending days of the batch culture when nutrients run steadily out of and more dead cells increased. Therefore, this type of wastewater is appropriate for the proliferation of these algae of interest, the optima wastewater of $75 \%$ for Tetraselmis suiscica and Platymonas sp, 50\% for Tetraselmis sp. even though their growth and weight of biomass in the optimal wastewater is moderately less than those in Daigo's IMK.

Table 1. Biomass of algae species on the day of highest cell number (optimal days)

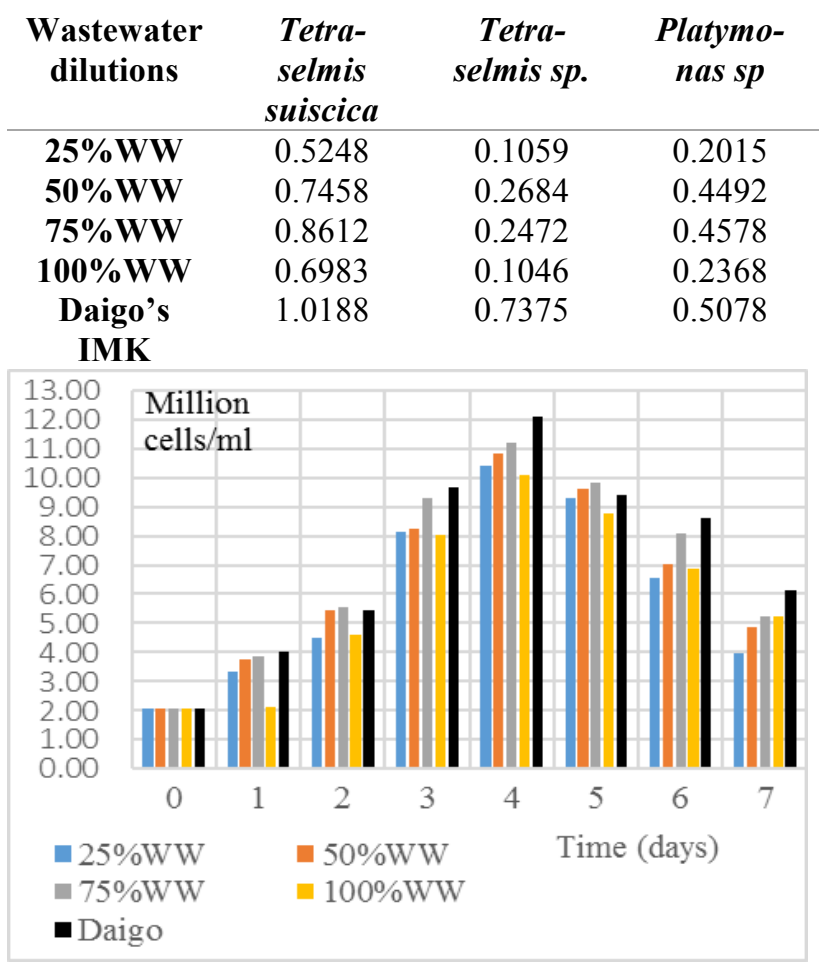

Figure 2. Changes in cell number of Tetraselmis suiscica during the batch culture 


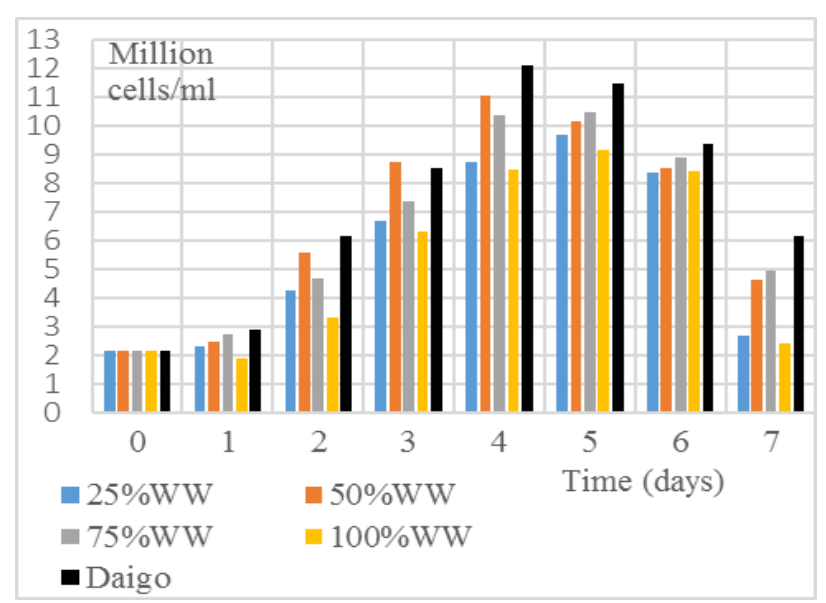

Figure 3. Changes in cell number of Tetraselmis sp. during the batch culture

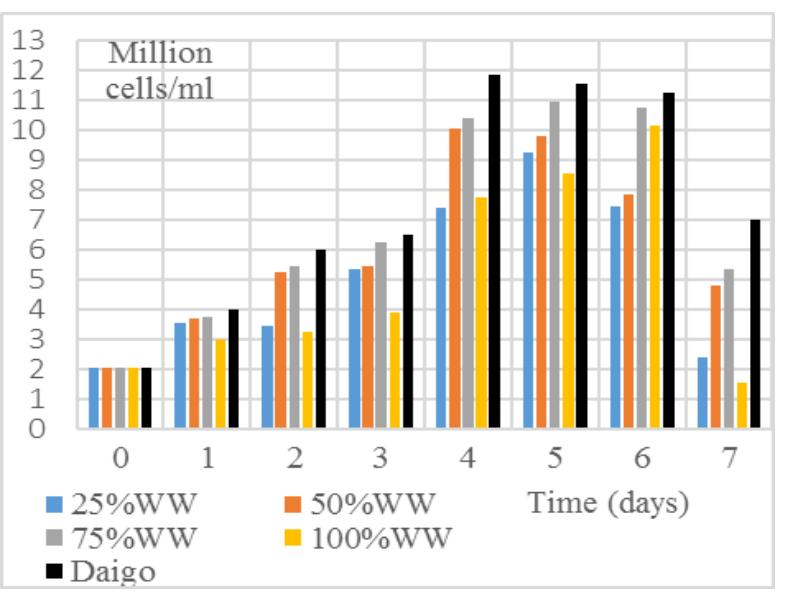

Figure 4. Changes in cell number of Platymonas sp. during the batch culture

\subsection{The function of algae species in removals of COD, total nitrogen, nitrate, ammonia and phosphorus}

Based on duplicates of determination of concentrations ( $\mathrm{mg} / \mathrm{l})$ of COD, nitrate, ammonium ion and total phosphorus, these components were in wastewater with a high amount even in the most diluted sample (Table 2).

Table 2. Concentrations of COD, nitrate, ammonium ion and total phosphorus before treatment

\begin{tabular}{ccccc}
$\begin{array}{c}\text { Wastewater } \\
\text { dilutions \% }\end{array}$ & $\begin{array}{c}\mathbf{C O D} \\
\mathbf{m g} / \mathbf{l}\end{array}$ & $\begin{array}{c}\mathbf{N}^{-N_{\mathbf{3}}}{ }^{-} \\
\mathbf{m g} / \mathbf{l}\end{array}$ & $\begin{array}{c}\mathbf{N}^{-N_{4}}{ }^{-} \\
\mathbf{m g} / \mathbf{l}\end{array}$ & $\begin{array}{c}\mathbf{P}_{-} \mathbf{P O}_{\mathbf{4}}{ }^{3-} \\
\mathbf{m g} / \mathbf{l}\end{array}$ \\
\hline $\mathbf{2 5}$ & 320 & 0.713 & 18.9 & 1.996 \\
$\mathbf{5 0}$ & 480 & 1.206 & 20.5 & 3.954 \\
$\mathbf{7 5}$ & 576 & 1.703 & 26.1 & 4.059 \\
$\mathbf{1 0 0}$ & 672 & 2.184 & 28.7 & 5.058
\end{tabular}

As can be seen from Table 3, levels of COD, nitrate, ammonium ion and phosphorus were steadily reduced by single Tetraselmis suiscica, Tetraselmis sp., Platymonas $s p$ after a week incubation in wastewaters with different dilutions, $25 \%, 50 \%, 75 \%$ and $100 \%$, then significantly in the beginnings of the second week and eventually rose slightly in the ends of the batch culture when "nutrients" wastewater pollutants was absent in very small amountwhilst wastes of algae as well as the cells of other microorganisms harming to algae increased, thus dead algae cells is more than alive cells.

Equivalent to the reduction of pollutants' concentrations, treatment yields increased when concentrations decreased apart from some cases, yields remained stable in the eighth, ninth days of the batch (marked as days 4, 5, 6 in Figures). Yields of COD removal of Platymonas $s p$ in Figure 5 as the example, the yield reached the plateau of nearly $86.67 \%$, equivalent to $64 \mathrm{mg} / 1$ in wastewater dilution of $50 \%$.

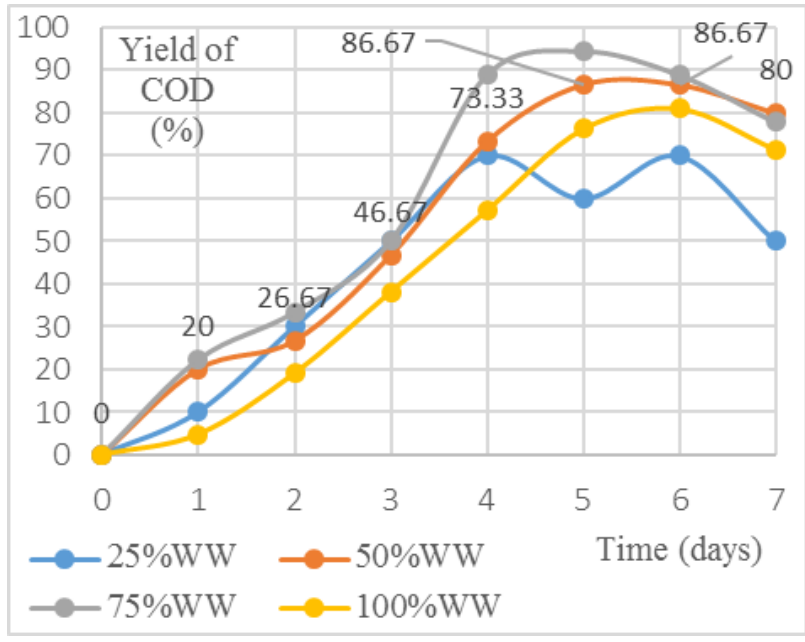

Figure 5. Yields of COD removal of Platymonas sp. during the batch culture

In the one hand, when the wastewater was much diluted, to $25 \%$, the yields were smaller than those in more concentrated wastewaters, which was possibly owing to the insufficient supply of nutrient available in wastewater for algae proliferation, particularly in cases of ammonia removals of Tetraselmis $s p$ in Figure 6, the maximum yield was only $35 \%$ equivalent to $12.3 \mathrm{mg} / \mathrm{l}$ in wastewater dilution of $25 \%$ whereas the yield obtained up to nearly $70 \%$, equivalent to $6-7 \mathrm{mg} / \mathrm{l}$ in the dilution of dilution of $50 \%$.

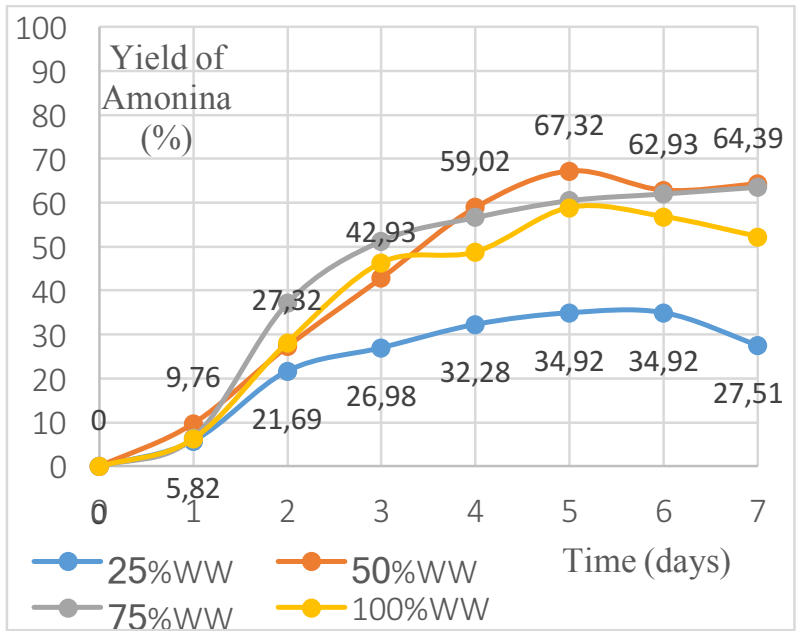

Figure 6. Yields of ammonia removal of Tetraselmis sp. during the batch culture 
Table 3. Changes in concentrations of COD, nitrate, ammonia and total phosphorous as well as yields of removals of these substances during the batch culture

\begin{tabular}{|c|c|c|c|c|c|c|c|c|c|c|c|c|}
\hline & & Day & & & & & & & & & & \\
\hline & & $\mathbf{W W}$ & $\mathbf{C}$ & $\mathbf{Y}$ & $\mathbf{C}$ & $\mathbf{Y}$ & $\mathrm{C}$ & $\mathbf{Y}$ & C & $\mathbf{Y}$ & $\mathbf{C}$ & $\mathbf{Y}$ \\
\hline & & $\%$ & mg/l & $\%$ & $\mathrm{mg} / \mathrm{l}$ & $\%$ & mg/l & $\%$ & $\mathrm{mg} / \mathrm{l}$ & $\%$ & $\mathrm{mg} / \mathrm{l}$ & $\%$ \\
\hline Tetra- & C & 25 & 288 & 10 & 256 & 20 & 192 & 40 & 128 & 60 & 192 & 40 \\
\hline selmis & $\mathbf{O}$ & 50 & 448 & 6.67 & 384 & 20 & 160 & 66.67 & 96 & 80 & 128 & 73.33 \\
\hline suis- & D & 75 & 416 & 27.78 & 416 & 27.78 & 128 & 77.78 & 96 & 83.33 & 160 & 72.22 \\
\hline cica & & 100 & 544 & 19.05 & 448 & 33.33 & 256 & 61.9 & 160 & 76.19 & 192 & 71.43 \\
\hline & N- & 25 & 0.684 & 4.07 & 0.559 & 21.6 & 0.469 & 34.22 & 0.233 & 67.32 & 0.235 & 67.04 \\
\hline & $\mathrm{NO}_{3}{ }^{-}$ & 50 & 1.110 & 7.96 & 0.993 & 17.66 & 0.801 & 33.58 & 0.268 & 77.78 & 0.456 & 62.19 \\
\hline & & 75 & 1.421 & 16.56 & 1.154 & 32.24 & 0.841 & 50.62 & 0.218 & 87.2 & 0.306 & 82.03 \\
\hline & & 100 & 2.027 & 7.19 & 1.785 & 18.27 & 1.329 & 39.15 & 1.035 & 52.61 & 1.049 & 51.97 \\
\hline & N- & 25 & 18.1 & 4.23 & 16.4 & 13.23 & 10.4 & 44.97 & 11.5 & 39.15 & 12.9 & 31.75 \\
\hline & $\mathrm{NH}_{4}{ }^{+}$ & 50 & 18.7 & 8.78 & 15.7 & 23.41 & 11.7 & 42.93 & 7.6 & 62.93 & 7.9 & 61.46 \\
\hline & & 75 & 23.7 & 9.2 & 18.8 & 27.97 & 13.9 & 46.74 & 9.3 & 64.37 & 10.5 & 59.77 \\
\hline & & 100 & 26.5 & 7.67 & 20.5 & 28.57 & 13.3 & 53.66 & 11.6 & 59.58 & 12.1 & 57.84 \\
\hline & P- & 25 & 1.368 & 31.46 & 1.117 & 44.04 & 0.938 & 53.01 & 0.465 & 76.7 & 0.470 & 76.45 \\
\hline & $\mathrm{PO}_{4}{ }^{3-}$ & 50 & 2.220 & 43.85 & 1.986 & 49.77 & 1.602 & 59.48 & 0.536 & 86.44 & 0.912 & 76.93 \\
\hline & & 75 & 2.843 & 29.96 & 2.308 & 43.14 & 1.681 & 58.59 & 0.436 & 89.26 & 0.612 & 84.92 \\
\hline & & 100 & 4.054 & 19.85 & 3.570 & 29.42 & 2.659 & 47.43 & 2.070 & 59.07 & 2.099 & 58.5 \\
\hline Tetra- & COD & 25 & 288 & 10 & 224 & 30 & 128 & 60 & 96 & 70 & 160 & 5 \\
\hline selmis & & 50 & 448 & 6.67 & 320 & 33.33 & 32 & 93.33 & 96 & 80 & 128 & 73.33 \\
\hline sp. & & 75 & 512 & 11.11 & 416 & 27.78 & 96 & 83.33 & 160 & 72.22 & 224 & 61.11 \\
\hline & & 100 & 640 & 4.76 & 608 & 9.52 & 352 & 47.62 & 288 & 57.14 & 320 & 52.38 \\
\hline & N- & 25 & 0.678 & 4.91 & 0.613 & 14.03 & 0.212 & 70.27 & 0.247 & 65.36 & 0.222 & 68.86 \\
\hline & $\mathrm{NO}_{3}^{-}$ & 50 & 1.141 & 5.39 & 1.035 & 14.18 & 0.099 & 91.79 & 0.193 & 84 & 0.252 & 79.1 \\
\hline & & 75 & 1.54 & 9.57 & 1.354 & 20.49 & 0.469 & 72.46 & 0.425 & 75.04 & 0.868 & 49.03 \\
\hline & & 100 & 2.056 & 5.86 & 1.789 & 18.09 & 0.314 & 85.62 & 0.634 & 70.97 & 1.047 & 52.06 \\
\hline & N- & 25 & 17.8 & 5.82 & 14.8 & 21.69 & 12.8 & 32.28 & 12.3 & 34.92 & 13.7 & 27.51 \\
\hline & $\mathrm{NH}_{4}{ }^{+}$ & 50 & 18.5 & 9.76 & 14.9 & 27.32 & 8.4 & 59.02 & 7.6 & 62.93 & 7.3 & 64.39 \\
\hline & & 75 & 24.4 & 6.51 & 16.4 & 37.16 & 11.3 & 56.7 & 9.9 & 62.07 & 9.5 & 63.6 \\
\hline & & 100 & 26.9 & 6.27 & 20.6 & 28.22 & 14.7 & 48.78 & 12.4 & 56.79 & 13.7 & 52.26 \\
\hline & P- & 25 & 1.743 & 12.68 & 1.608 & 19.44 & 0.856 & 57.11 & 0.456 & 77.15 & 0.442 & 77.86 \\
\hline & $\mathrm{PO}_{4}{ }^{3-}$ & 50 & 3.215 & 18.69 & 2.994 & 24.28 & 1.705 & 56.88 & 0.486 & 87.71 & 0.852 & 78.45 \\
\hline & & 75 & 3.654 & 9.98 & 3.415 & 15.87 & 1.865 & 54.05 & 0.582 & 85.66 & 0.844 & 79.21 \\
\hline & & 100 & 4.514 & 10.76 & 3.858 & 23.72 & 2.715 & 46.32 & 2.325 & 54.03 & 2.385 & 52.85 \\
\hline Platy- & COD & 25 & 224 & 10 & 224 & 30 & 96 & 70 & 96 & 70 & 160 & 50 \\
\hline monas & & 50 & 352 & 20 & 320 & 26.67 & 128 & 73.33 & 64 & 86.67 & 96 & 80 \\
\hline sp. & & 75 & 384 & 22.22 & 416 & 33.33 & 64 & 88.89 & 64 & 88.89 & 128 & 77.78 \\
\hline & & 100 & 544 & 4.76 & 608 & 19.05 & 288 & 57.14 & 128 & 80.95 & 192 & 71.43 \\
\hline & N- & 25 & 0.669 & 6.17 & 0.54 & 24.26 & 0.404 & 43.34 & 0.18 & 74.75 & 0.212 & 70.27 \\
\hline & $\mathrm{NO}_{3}^{-}$ & 50 & 1.158 & 3.98 & 0.953 & 20.98 & 0.843 & 30.1 & 0.224 & 81.43 & 0.394 & 67.33 \\
\hline & & 75 & 1.618 & 4.99 & 1.265 & 25.72 & 0.978 & 42.57 & 0.364 & 78.63 & 0.425 & 75.04 \\
\hline & & 100 & 2.054 & 5.95 & 1.63 & 25.37 & 1.133 & 48.12 & 0.847 & 61.22 & 0.744 & 65.93 \\
\hline & N- & 25 & 17.7 & 6.35 & 14.5 & 23.28 & 9.7 & 48.68 & 9.4 & 50.26 & 9.8 & 48.15 \\
\hline & $\mathrm{NH}_{4}{ }^{+}$ & 50 & 19.3 & 5.85 & 14.6 & 28.78 & 8.9 & 56.59 & 8.5 & 58.54 & 8.3 & 59.51 \\
\hline & & 75 & 24.6 & 5.75 & 16.8 & 35.63 & 8.5 & 67.43 & 7.9 & 69.73 & 8.9 & 65.9 \\
\hline & & 100 & 25.3 & 11.85 & 18.3 & 36.24 & 11.6 & 59.58 & 10.3 & 64.11 & 9.1 & 68.29 \\
\hline & P- & 25 & 1.835 & 8.07 & 1.725 & 13.58 & 0.965 & 51.65 & 0.510 & 74.45 & 0.498 & 75.05 \\
\hline & $\mathrm{PO}_{4}{ }^{3-}$ & 50 & 3.651 & 7.66 & 2.972 & 24.84 & 1.705 & 56.88 & 0.548 & 86.14 & 0.853 & 78.43 \\
\hline & & 75 & 3.826 & 5.74 & 2.889 & 28.82 & 1.615 & 60.21 & 0.459 & 88.69 & 0.928 & 77.14 \\
\hline & & 100 & 4.729 & 6.50 & 3.581 & 29.20 & 2.058 & 59.31 & 2.187 & 56.76 & 2.247 & 55.58 \\
\hline
\end{tabular}

In the other hand, when the wastewater was much concentrated, to $100 \%$ (the origin), the yields were smaller than those in more diluted wastewaters, which was feasibly on account of the excess of nutrients beyond the tolerance of algae. This was especially observed in the cases of phosphorus removals of all studied algae. For instance, results of Tetraselmis suiscica in Figure 7, the maximum yield was under $60 \%$, equivalent to $2.1 \mathrm{mg} / 1$ in wastewater dilution of $100 \%$ whereas the yield obtained up to nearly $90 \%$, equivalent to $0.4 \mathrm{mg} / \mathrm{l}$ in the dilution of dilution of $75 \%$. 


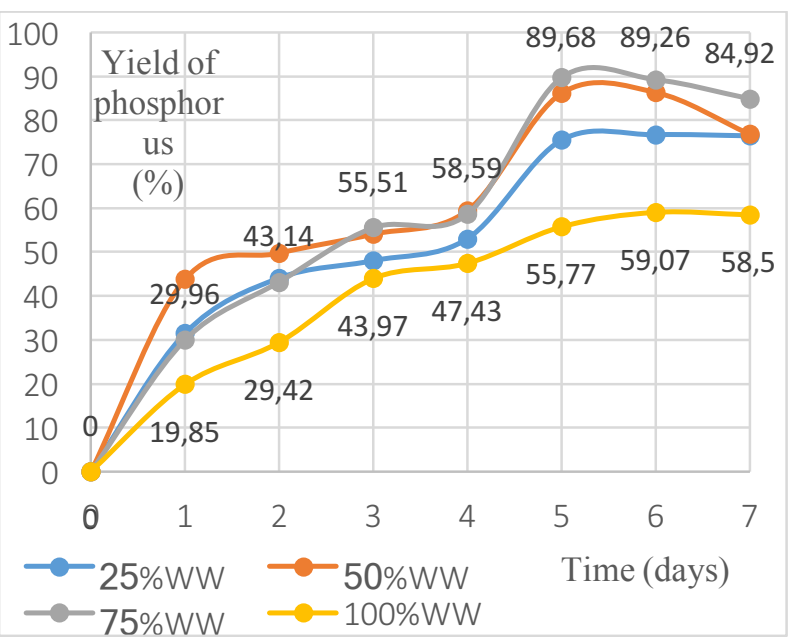

Figure 7. Yields of phosphorus removal of Tetraselmis suiscica during the batch culture

From the results of changes in total nitrogen determined in the first day of the batch and the optimal days of each species when the growth rate is maximum (table 4), it is concluded that these algae had the same high performances (over 70\%) in eliminating nitrogen from wastewater even in the cases of concentrated wastewaters, particularly $83.9 \%, 81.8 \%, 76.2 \%$ in the decreasing order of Platymonas sp, Tetraselmis suiscica, Tetraselmis sp., respectively in the environment of $75 \% \mathrm{WW}$.

Table 4. Changes in total nitrogen (TN) and yields of TN removals during the batch culture

\begin{tabular}{ccccccccc}
\multirow{2}{*}{ WW } & $\begin{array}{c}\text { Input } \\
\text { (mg/l) }\end{array}$ & \multicolumn{2}{c}{$\begin{array}{c}\text { Tetraselmis } \\
\text { suiscica }\end{array}$} & \multicolumn{2}{c}{$\begin{array}{c}\text { Tetraselmis } \\
\text { sp. }\end{array}$} & \multicolumn{2}{c}{$\begin{array}{c}\text { Platymonas } \\
\text { sp }\end{array}$} \\
\cline { 3 - 9 } & & $\begin{array}{c}\text { Out- } \\
\text { put }\end{array}$ & H $\%$ & $\begin{array}{c}\text { Out- } \\
\text { put }\end{array}$ & H\% & Out- & H\% \\
& & put & \\
$\mathbf{2 5 \%}$ & 7.36 & 4.36 & 40.8 & 4.41 & 40.1 & 2.41 & 67.3 \\
$\mathbf{5 0 \%}$ & 10.89 & 2.78 & 74.5 & 1.97 & 81.9 & 3.15 & 71.1 \\
$\mathbf{7 5 \%}$ & 12.01 & 2.19 & 81.8 & 2.86 & 76.2 & 1.93 & 83.9 \\
$\mathbf{1 0 0 \%}$ & 13.31 & 4.25 & 68.1 & 4.24 & 68.1 & 4.24 & 68.1
\end{tabular}

\section{Conclusion}

The same as other microorganism, micro algae have a tremendous growth in almost environments even in various types of wastewater, such as effluents from citric acid and ethanol production (Valderrama et al., 2002), wastewater from municipal wastewater treatment plants (Wang et al., 2010 ) with a plethora of components in wide ranges of concentration owing to abilities of using and transferring polluting substances into nutrients essential for building their bio-materials, for example, using phosphates in wastewater to synthesize ATP, phospholipases and DNA, utilizing nitrogen compounds to produce acid amines and proteins.

In this report, Tetraselmis suiscica, Tetraselmis sp., Platymonas $s p$. virtually proliferated quickly and reduce significantly substances polluting mariculture effluents from shrimp ponds at Can Gio District, Ho Chi Minh City, Vietnam. Although cell density declined in the end of the batch after maximum days in the middle of the batch, it was still higher than the cell number in the beginnings, approximately 4-5 million cells $/ \mathrm{ml}$. Similarly, there was a general trend in changes in yields of removal of COD, total nitrogen (Kjeldahl nitrogen), nitrate, ammonium ion and phosphorus, the frequencies rocketed to highest values on optimal days in the middle of the batch, particularly $80-90 \%$,
$70-80 \%$, over $70 \%, 60-70 \%$ and $70-80 \%$ respectively, and then fell down in the ends but remained around $50 \%$ in appropriate wastewater dilutions.

Amongst studied algae species, Tetraselmis suiscica and Platymonas sp. could develop well and give more biomass in more concentrated wastewater than Tetraselmis sp., $75 \% \mathrm{WW}$ compared to $50 \% \mathrm{WW}$, especially Tetraselmis suiscica with the highest biomass weight, 0.8612 in wastewater of $75 \%$, and $1.0188 \mathrm{~g} / 100 \mathrm{ml}$ in Daigo's IMK. On behalf of performances of reducing pollutants in the optimal wastewater dilutions and on maximum days, Tetraselmis sp. and Platymonas sp. gave higher treatment yields of COD, $93.33 \%$ and $88.89 \%$; Tetraselmis $s p$. gave the highest treatment yields of nitrate, $91.79 \%$; Platymonas $s p$. gave the highest treatment yields of ammonia, $74.71 \%$. All of them eliminated well total nitrogen and total phosphorus with the efficiency of $80 \%$ and $85 \%$, respectively, which demonstrates that in suitable kinds of wastewater, these algae remove phosphorus better than Chlorella vulgaris, which gives slightly small yields in total phosphorus removal (Valderrama et al., 2001; Li et al., 2011; Sriram and Seenivasan, 2012).

In the scope of study in small scale, Tetraselmis suiscica, Tetraselmis sp., Platymonas sp. shown their potentials in reducing significantly COD, nitrogen and phosphorus from wastewater of shrimp cultivation, from $672 \mathrm{mg} / 1$ to 100 $200 \mathrm{mg} / \mathrm{l}$ of COD, from $2.18 \mathrm{mg} / 1$ to $0.5-1.0 \mathrm{mg} / 1$ of nitrate, from $28.7 \mathrm{mg} / 1$ to $9.0-10.0 \mathrm{mg} / 1$ of ammonium, from 5.06 $\mathrm{mg} / 1$ to $2.1-2.2 \mathrm{mg} / \mathrm{l}$ of phosphate, therefore hopefully they will be applied in wastewater treatment process in municipal wastewater treatment plants.

\section{References}

[1] Abdel-Raouf, A.A. Al-Homaidan, I.B.M. Ibraheem (2012). Microalgae and wastewater treatment. Saudi Journal of Biological Sciences, 19, 257-275.

[2] Agwa, O.K., Ibe, S.N and Abu, G.O. (2012). Biomass and lipid production of a fresh water algae Chlorella sp. using locally formulated media. Biodiesel Production, 3 (9), 288-295.

[3] Amit Kumar, Sarina Ergas, Xin Yuan, Ashish Sahu, Qiong Zhang, Jo Dewulf, F. Xavier Malcata and Herman van Langenhove. Enhanced $\mathrm{CO} 2$ fixation and biofuel production via microalgae: recent developments and future directions. Trends in Biotechnology, 28 (7), 371-380.

[4] Chun-Yen Chen, Kuei-Ling Yeha, Rifka Aisyah, Duu-Jong Leec, Jo-Shu Chang (2011). Cultivation, photobioreactor design and harvesting of microalgae for biodiesel production: A critical review. Bioresource Technology, 102, 71-81.

[5] Gouveia, L. and Oliveira, A.C. (2009). Microalgae as a raw material for biofuels production. J. Ind. Microbiol. Biotechnol, 36 (2), 269-274.

[6] J. K. Pittman, Andrew P. Dean, Olumayowa Osundeko (2011). The potential of sustainable algal biofuel production using wastewater resources. Bioresource Technology, 102, 17-25.

[7] Laura Barsanti and Paolo Gualtieri (2006). Algae, 
Anatomy, Biochemistry, and Biotechnology, the United States of America, Taylor \& Francis.

[8] Lee, KL. Wangyong and Lee, Choul-Gyun (2001). Effect of Light/dark Cycles on Wastewater Treatments by Microalgae. Biotechnol. Bioprocess Eng, 6, 194-199.

[9] Logan Christenson and Ronald Sims (2011). Production and harvesting of microalgae for wastewater treatment, biofuels, and bioproducts. Biotechnology Advances, 29, 686-702.

[10] Michael Hannon, Javier Gimpel, Miller Tran, Beth Rasala, and Stephen Mayfield (2010). Biofuels from algae: challenges and potential. Biofuels, 1 (5), 763 784

[11] Peer M. Schenk, Skye R. Thomas-Hall, Evan Stephens, Ute C. Marx, Jan H. Mussgnug, Clemens Posten, Olaf Kruse and Ben Hankamer (2008). Second Generation Biofuels: High-Efficiency Microalgae for Biodiesel Production. Bioenerg. Res., 1, $20-$ 43.

[12] I. Rawat, R. Ranjith Kumar, T. Mutanda, F. Bux (2011). Dual role of microalgae: Phycoremediation of domestic wastewater and biomass production for sustainable biofuels production. Applied Energy, 88, 3411-3424.

[13] Senthil Chinnasamy, Ashish Bhatnagar, Ryan W. Hunt, K.C. Das (2010). Microalgae cultivation in a wastewater dominated by carpet mill effluents for biofuel applications. Bioresource Technology, 101, 3097-3105.

[14] S. Sriram and R. Seenivasan (2012). Microalgae Cultivation in Wastewater for Nutrient Removal. J. Algal Biomass Utln, 3 (2), 9-13.
[15] Ting Cai, Stephen Y. Park, Yebo Li. (2013). Nutrient recovery from wastewater streams by microalgae: Status and prospects. Renewable and Sustainable Energy Reviews, 19, 360-369.

[16] L. T. Valderramaa, Claudia M. Del Campoa, Claudia M. Rodrigueza, Luz E. de- Bashana, , Yoav Bashan (2002). Treatment of recalcitrant wastewater from ethanol and citric acid production using the microalga Chlorella vulgaris and the macrophyte Lemna minuscula. Water Research, 36, 4185-4192.

[17] Yecong Li, Yi-Feng Chen, Paul Chen, Min Min, Wenguang Zhou, Blanca Martinez, Jun Zhu, Roger Ruan (2011). Characterization of a microalga Chlorella sp. well adapted to highly concentrated municipal wastewater for nutrient removal and biodiesel production. Bioresource Technology, 102, 51385144.

[18] Yusuf Chisti (2007). Biodiesel from microalgae. Biotechnology Advances, 25, 294-306.

[19] L. Wang \& Min Min \& Yecong Li \& Paul Chen \& Yifeng Chen \& Yuhuan Liu \& Yingkuan L. Wang \& Roger Ruan (2010). Cultivation of Green Algae Chlorella sp. in Different Wastewaters from Municipal Wastewater Treatment Plant. Appl Biochem Biotechnol, 162, 1174-1186

[20] Standard Method 5220-CHEMICAL OXYGEN DEMAND (COD)

[21] Standard Method 4500-NH3 C. Titrimetric Method.

[22] EPA 350.2. Nitrogen, Ammonia, 1974 (Colorimetric, Titrimetric, Potentiometric Distillation Procedure.

[23] Standard Method 4500-Phosphorus E. Ascorbic Acid Method.

[24] ISO 19458:2006. 